Антоніна Прокопенко кандидат філологічних наук, старший викладач кафедри германської філологї̈

Сумський державний університет, orcid.org/0000-0002-4590-4201

м. Суми, Украӥна, +38(066) 00811 52, a.prokopenko@gf.sumdu.edu.иa

Валерія Рава студентка групи ПР-62 кафедри германської філологї Сумський державний університет orcid.org/0000-0003-3111-6666 м. Суми, Україна, +38(066) 56049 73, valeriarava99@gmail.com

\title{
Гендерна диференціація комунікативних стратегій в англомовному мікроблогінгу
}

Анотація. У статті розглядаються комунікативні стратегї англомовних мікроблогерів, які вони використовують під час проведення інтерв'ю. Основний фокус уваги зосереджено саме на тендерному аспекті використання комунікативних стратегій. Задля об'єктивної оиінки у запропонованому дослідженні аналізується комунікативна поведінка різностатевих та різновікових блогерів, з різною тематичною орієнтацією інтерв'ю. Виокремлені певні групи лексичних одиниць допомогли схарактеризувати тенденцію їх вживання поміж жінок- та чоловіківблогерів. Також, визначено тендерну складову комунікативних стратегій $i$ технік, якими користуються блогери. Аналіз базується на лінгвістичному, лінгвосеміотичному та лінгвостилістичному аспектах.

Ключові слова: блогер, мікрлоблог, тендер, вербальна поведінка, комунікативні стратегії, диферениіація, фемінність, мускулінність.

Abstract. The article introduces the results of the given research in the field of microblogging. It deals with the communicative strategies of English-speaking micro bloggers that are used in the interview. The linguistic aspects of verbal behaviour of English-speaking bloggers are analysed in detail. Namely, the main attention is focused on gender aspect of the using of communicative strategies. Some groups of bloggers, which are subdivided by sex, age and thematic orientation, were selected in order to fulfil this research. Designated groups of lexical units helped to characterize the tendency of their use among women and men-bloggers. The linguistic features of both bloggers' sexes are revealed. The analysis is based on linguistic, linguistic-semiotic and linguistic-stylistic aspects. 
Keywords: blogger, microblogging, gender, verbal behaviour, communicative strategies, differentiation, masculinity, femininity.

Вступ Наприкінці XX століття з'явився новий напрямок у науці антропологічна лінгвістика. Ця галузь знань зосереджена на детальному вивченні мовної особистості в конкретному дискурсі. Досить активно відбуваються дослідження та аналіз мовлення 3 посиланнями на феномен статі, та не біологічної, а соціальної, тобто гендеру. Сучасна лінгвістика виходить з положення про те, зазначає Ю.П.Маслова, що гендер - це причина того, що чоловіки та жінки по-різному використовують мову («я говорю таким чином, тому що я жінка/чоловік») [5].

Поняття «ґендер» полягає в різниці між чоловіками та жінками в багатьох аспектах, таких як: особливості психіки та поведінки в соціумі, соціальні ролі, біологічні та мовленнєві ознаки, сформовані культурним середовищем. Беручи до уваги лінгвістичний аспект такого феномену як гендер, можна виділити дві групи проблем, які охоплює цей напрямок. Тож, по-перше це відображення статі при проведенні мовленнєвого аналізу (лексика, синтаксис, номінативна система, стилістичні засоби, категорія роду тощо, по-друге вербальна поведінка жінок та чоловіків.

Незважаючи на проведену низку лінгвістичних досліджень, які $є$ гендерно спрямованими, все ще не можна стверджувати, що цей напрямок $\epsilon$ цілком вивченим. За приклад можна взяти той факт, що до сьогодні в науковому просторі не склалася єдино-вірна концепція вивчення гендеру. Причиною цього $є$ те, що комунікативна поведінка як жінок, так і чоловіків не аналізується комплексно, та й більше уваги, все ж таки, приділяють фемінності, ніж маскулінності. Знання особливостей спілкування має чимало плюсів, а от знання, які зосереджені на гендерному концепті, дають можливість виокремити певні комунікативні стратегії та дотримуватися їх, уникаючи мовленнєвих невдач, водночас це не-аби-як сприяє взаєморозумінню між двома статями, а також виявляє певні гендерні стереотипи, і не тільки.

Мовлення блогерів, що є їхньою візитною карткою, зазнає впливу фактору гендера. Ця теза постулюється у працях О. Л. Бессонової, Н. Д. Борисенко, Ю. П. Мельник, А. М. Волобуєвої, Н. Ф. Остапенко, Н. М. Сидоренко, Р. І. Федосієвої, Ю. П. Маслової, О. А. Вороніної, О. М. Здравомислової, Н. І. Ажгихіної.

Жіноче та чоловіче мовлення має свої особливості, відмінні та подібні риси. Мова не тільки виражає культурні погляди на гендер, але і утворює гендерну ідентичність особистості [6, с. 102]. Приналежність індивіда до певної професійної, соціальної, гендерної чи вікової групи, сукупність норм та традицій народу, що визначаються культурою суспільства, називається комунікативно поведінкою. Існування гендерлектів зумовлено впливом 
соціальної статі на вербальну та невербальну комунікацію. Тим не менш, не можна впевнено стверджувати, що існують чоловіча і жіноча мови.

Метою цієї статті $є$ вивчення характерних рис комунікативної поведінки жінок- та чоловіків-блогерів. Об'єктом дослідження $\epsilon$ комунікативні стратегії в англомовних мікроблогах, а предметом - лексичні одиниці, які використовуються у комунікативних стратегіях блогерів 3 огляду на їхню гендерну приналежність.

Дослідження є актуальним 3 двох причин. Перша - воно пов'язане 3 перспективним напрямком вивчення мови - лінгвістичною гендерологією, $\mathrm{i}$, друга - спробою вирішити протиріччя, що виникають внаслідок активного залучення сучасних людей в Інтернет-комунікацію англійською мовою, 3 одного боку, і суттєвої ймовірністю порушення комунікації, пов'язаною 3 нерозумінням гендерних особливостей англомовного тексту, 3 іншого. Вивчення гендеру в дискурсі мікроблогів $є$ перспективним, у зв'язку з тією роллю яку вони відіграють у створенні соціальної реальності, як специфічна форма Інтернет-комунікації. Текст особистого блогу відрізняється не тільки здатністю відтворювати культурні цінності, нормативні зразки і моделі поведінки, але й можливістю швидко відображати зміни в суспільстві, зміну культурних орієнтирів, а значить, $€$ репрезентативним матеріалом для виявлення гендерних уявлень, характерних для конкретного соціуму в конкретний історичний період.

Методи і методологія дослідження. Основним методом дослідження виступає контрастивний аналіз, що уможливлює порівняння та виокремлення диференційних ознак чоловічого та жіночого мовлення у дискурсі мікроблогінгу. На основі дискурс-аналізу здійснено дослідження комунікативної поведінки блогерів. У межах структурно-семантичного аналізу проаналізовано поверхневі та глибинні структури лексичних одиниць, що входять до складу комунікативних стратегій блогерів. Також було застосовано евристичний метод, що передбачає зібрання раніше зафіксованого матеріалу дослідження, тобто англомовних відео-блогів.

У якості матеріалу вивчення, методом випадкової вибірки було відібрано по 50 англомовних відеоблогів чоловіків та жінок за 2018-2019 рр. Аналіз проводився при використанні таких сайтів: Youtube, Livejournal, особистих веб-сайтів блогерів та блоги англійських авторів порталу «UK Bloggers».

\section{Виклад основного матеріалу та обговорення результатів дослідження}

Блогінг - не лише популярний та затребуваний вид діяльності, а й досить нова форма комунікації, що відображає важливість гендерного феномену як для життя окремої особистості, так і для організації соціуму. Блог містить огляди на різні тематики, коментарі, статті, часто відео та фото, які надає автор, тобто «блогер». Як зазначає Б. Нарді, блог - це веб-сторінка, замислом якої є регулярне оновлення записів, зображень чи мультимедіа. Основним призначенням блогу $є$ надання користувачам інструменту для 
самопрезентації, пошуку однодумців, побудови мережі взаємодії [8]. Блогери різної статі обирають диферентні вербальні та невербальні комунікативні стратегії у своїй вербальній поведінці.

Також, О.Л. Бєссонова, провівши дослідження, зазначила, що гендерний фактор має великий вплив на світогляд та на вербалізацію мовленнєвої поведінки жінок та чоловіків $[4,39]$.

Відмінності між чоловічою і жіночою мовою можна помітити на різних рівнях мови: на лексичному, фонетичному, граматичному та стилістичному. Окрім цього існують розбіжності і в тактиці побудови промови. Зазначимо, що найбільш помітними є відмінності мовлення на лексичному рівні. Так, О. А. Земська, М. В. Китайгородська і Н. М. Розанова вказують, що характерними ознаками жіночого мовлення $є$ тенденція до гіперболізації та висока концентрація експресивно-оцінних слів [3]. На підтвердження цих слів наведемо інтерв'ю відомого спікера TED Talks Brené Brown's. Ï̈̈ блог присвячений реаліям життя, де вона розповідає як бути мотивованим та сфокусованим серед хаосу повсякдення. "If you ask me: What's the most terrifying difficult emotion that we experience, I would say joy" [11].

$\mathrm{У}$ той час, як чоловікам характерна згрубілість мови - нецензурна лексика. Так, наприклад, PewDiePie блогер з Великої Британії, досить часто використовує лайливі слова: “Oh, look, it's more people pointing out that I'm an idiot", "Well, that's why you need to subscribe god dammit" [22]. Та не лише він зловживає гострими слівцями, до нього долучився Caspar: "I got millions of subscribers on YouTube, millions on Instagram and Twitter, and only 1 million on Facebook, what the fuck Mark Zuckerberg? Was my Facebook content that bad?" [10]. Joel from 'GALLUKS': "You always look like a whore" [16], та Evan Carmichael: "Even if the result is suck" [13]. Як пише О. Есперсен, у порівнянні з чоловіками, жінки більш схильні до вживання евфемізмів, аніж лайок $[9$, с. 250].

Та не лише нецензурна лексика є характерною для маскулінної групи блогерів. Серед чоловіків існує тенденція до використання стилістично нейтральної лексики та вживання термінів. Ось, наприклад, для Evan Carmichael характерними є обидві риси: "Live life without fear" [12]. "I see entrepreneurs and leaders as trees. You are tree, your responsibility is a tree, is to eat poison carbon dioxide, right you eat poison, you eat it, you grow from it and then you spit out positivity and oxygen for the people around you, right, for yourself and for people around you" [13]. Jim Chapman: "The information we have about it is quite dichotomous" [15]. Цей приклад слугує не лише підтвердженням тренду серед чоловіків використовувати терміни в мовленні, а й вказує на ще одну характеристику - використання професійних знань поза сферою професійного спілкування.

Також О. А. Земська, М.В.Китайгородська і зазначають, що жінки досить часто задля вираження позитивної оцінки вживають прикметники, прислівники та експресивні синоніми [2]. 
Прикладом $є$ слова 3 відео-блогу Megan Ellaby: "I've got some amazing amazing pieces from a variety of different brands" [18]. Mel Robins: "I was brand-new young attorney" [20]. Gabrielle Bernstein: "Really asking for clear direction is a really amazing tool for getting signs" [14]. Крім того, жінки вживають більшу кількість займенників, прислівників, дієслів та часток. Яскравим прикладом є відео Gabrielle Bernstein під назвою "How to Receive Signs from the Universe" "We're always getting guided, regardless of whether we're receiving the exact message we want" [17].

Стосовно чоловіків, то вони, у свою чергу, вживають прикметники, в основному, у найвищому ступені порівняння. PewDiePie: "Now edit this bit, the coolest way, possible" [21]. Simon Minter 'MINIMITER' "I've hurt his bank account and that's the most important thing" [20]. Caspar: "I did the smartest thing you can so when you have quite a lot of cash". "I made a decision probably the riskiest decision of my life". "You are not the brightest spark in a toolbox" [10].

Жінки, у порівнянні з чоловіками, більш схильні до вживання вигуків, найчастішим з яких є "oh”, “oh my God" "wow”. Brené Brown " oh my God, this is so huge". "Wow, works going good, good relationship with my partner, parents seem to be doing okay" [11].

Н. Л. Пушкарьова відзначає, що характерними для жінок є окличні та питальні речення, деякі використовують риторичні запитання, вони використовують розгорнуті, детальні та емоційно-забарвленні речення. У той час, як є більш лаконічними, предметними та менш динамічними при побудові тексту [7, с. 32]. Зі стилістичної точки зору, жінкам властиво вживати ономатопею задля більшого експресивного забарвлення мови. Mel Robbins: "Everyone talks about passion, legacy purpose, blah blah blah blah!". "Terrified, absolutely terrified!". "Instead of trying to think: What's my purpose? What's my passion? What's my purpose? What's my Passion?" [20]. LDShadow Lady: “Oh, yes! Okay, that's no, noo!! [17].

Фемінний тип мовлення включає в себе використання ідіом з метою стилістичного забарвлення та більшої виразності. Brené Brown: "The other shoes gonna drop". "Bit vulnerability to the punch" [10]. DShadow Lady: "So if that's sounds like your cup of tea, then hit the subscribe button for more" [17].

За спостереженням О. Есперсена, на рівні синтаксису також існують певні розбіжності. У мовленні жінок присутні еліптичні конструкції та паратаксис, а чоловіки надають перевагу - періодам і гіпотаксису [9, с. 250]. Mel Robbins: "Whatever energizes you, naturally expands you, feels like possibility, is exiting to do it or may be scary, that's doesn't matter" [19]. Brené Brown: "I think, one of the thing that happens in a culture of scarcity is we're all chasing the extraordinary and we forget; like when I interviewed people, who went through horrific things: the loss of children, genocide, violence, trauma and I talked to them about what's the hardest loss, they have never talked about the extraordinary things, they said: "amidst the ordinary moments" [11]. 
Evan Carmichael: "If you face difficulties and then quit, that's what you're teaching yourself, that's the story inside your head, and there is no way you are gonna go off and accomplish those big bad impossible dream goals of yours" [13].

Тож, головну роль у мовленнєвому процесі відіграє застосуваннярізних комунікативних стратегій та тактик. Поняття комунікативної стратегії полягає в тому, щоб реалізувати наміри мовця, задля досягнення поставленої мети. Тобто блогер має чітко контролювати та обирати дієві прийоми спілкування, а також уміти їх змінювати, у випадку, коли щось піде не за планом. Реалізація стратегії залежить лише від мовця, адже задля правильної побудови, він має володіти певними знаннями та навичками, та розуміти про вплив соціальних чинників [1, 344].

Проаналізувавши англомовні відео-блоги чоловіків та жінок, нам вдалося виокремити класи слів, притаманні жіночому та чоловічому мовленню.

\begin{tabular}{|c|c|}
\hline Class & Simple words \\
\hline \multicolumn{2}{|r|}{ Female } \\
\hline GROOM & $\begin{array}{l}\text { Cleaner, washer, perfume, shaved, shampoo, cleansing, soap, } \\
\text { shower, toothpaste }\end{array}$ \\
\hline SLEEP & $\begin{array}{l}\text { tiresome, sleeping, dazed, sleeps, insomnia, napping, siesta, } \\
\text { nightmare, dreams }\end{array}$ \\
\hline I & mine, I \\
\hline FAMILY & $\begin{array}{l}\text { auntie, mommy, nephews, parents, daughter, motherhood, } \\
\text { grandma, wives, cousin }\end{array}$ \\
\hline EATING & $\begin{array}{l}\text { fat, dinner, tasting, drunken, fed, breakfast, cookie, tasted, } \\
\text { skinny, cookbook }\end{array}$ \\
\hline DISGUST & $\begin{array}{l}\text { sickening, revolting, horror, sick, offensive, obscene, } \\
\text { nauseous, wicked, offensive }\end{array}$ \\
\hline FEAR & $\begin{array}{l}\text { suspense, creep, dismay, fright, terrible, terror, afraid, scare, } \\
\text { alarmed, panicked }\end{array}$ \\
\hline SEWING & $\begin{array}{l}\text { mending, stitching, knitter, mend, tailor, suture, embroidery, } \\
\text { seamstress, needle }\end{array}$ \\
\hline PURPLENES & $\begin{array}{l}\text { purple, mauve, magenta, lilac, lavender, orchid, violet, } \\
\text { mauve, mulberry, purply }\end{array}$ \\
\hline SWEETNES & $\begin{array}{l}\text { syrup, honey, sugar, bakery, nectar, sweet, frost, sugary, } \\
\text { dessert, glaze, nut }\end{array}$ \\
\hline BRONNES & $\begin{array}{l}\text { coffee, biscuit, walnut, rust, berry, brown, brunette, } \\
\text { cinnamon, mahogany, caramel }\end{array}$ \\
\hline CHASTITY & $\begin{array}{l}\text { shame, elegant, decent, virtue, virgin, delicate, faithfulness, } \\
\text { platonic, purity, spotless }\end{array}$ \\
\hline \multicolumn{2}{|r|}{ Male } \\
\hline RELIG & $\begin{array}{l}\text { bless, satanism, angel, communion, spirit, lord, fa } \\
\text { immortal, theology, prayers }\end{array}$ \\
\hline
\end{tabular}




\begin{tabular}{|l|l|}
\hline METAPH & $\begin{array}{l}\text { suicide, meditation, cemetary, temples, drained, } \\
\text { immortalized, mercy, mourning } \\
\text { running, jogged, pool, basketball, swimming, exercise, } \\
\text { fitness, teams, aerobic } \\
\text { show, ad, comedies, tv, actors, drama, soaps, video, theaters, } \\
\text { commercials, films } \\
\text { credentials, department, financials, desktop, manage, } \\
\text { employ, work, career }\end{array}$ \\
JOB & $\begin{array}{l}\text { finalist, rival, enemy, competitor, foe, opposite, defendant, } \\
\text { player, dissident } \\
\text { creed, scholastic, religious, secularism, theology, religion, } \\
\text { divine, faith, dogma } \\
\text { evenness, constancy, persistence, accordance, steadiness, } \\
\text { firmness, stability } \\
\text { automotive, process, industrial, manufacture, measure, } \\
\text { construction, technician } \\
\text { power, force, weak, weakness, inflexible, ineffective, } \\
\text { charisma, charm, wimpy }\end{array}$ \\
UNIFORMITY & \\
ENGINEERINGUENCE
\end{tabular}

Табл. 1

Фемінність та маскулінність яскраво виражені у вербальній поведінці англомовних блогерів. Обираючи різні комунікативні стратегії, чоловіки та жінки, тим самим підкреслюють свої диференті особливості, як на лексичному, фонетичному, стилістичному, так і на синтаксичному рівнях.

Висновки. У результаті проведеного дослідження, яке мало на меті проаналізувати комунікативну поведінку мікроблогерів, нам вдалося з'ясувати, що вона має гендерну маркованість, яка виражається у приналежності до категорій фемінності та маскулінності. Було виокремлено специфічні гендерні характеристики, які також можуть залежати від індивідуальних особливостей, таких як: вік, соціальний статус, національна приналежність.

Отже, у вербальній поведінці чоловікам-блогерам властиві: точність номінації, стилістично нейтральна лексика, використання багажу професійних знань, лаконічні та менш динамічні тексти, чіткість, прямота, інформативність, однозначність, використання термінів, сленгу та ненормативної лексики, побудова простих, інколи синтаксичнонеправильних речень, швидкий темп розмови та інше. Жінкам-блогерам же притаманні такі риси: гіперболізована експресивність, багатослівність, вживання вигуків, розгорнуті експресивні речення, використання окличних речень та розділових запитань, розмова ведеться розмірено у ввічливій формі. Перспективу подальших досліджень вбачаємо у вивченні лінгвального аспекту специфічних трансформацій та новітніх практик, якими 
користуються сучасні блогери, а також маніпулятивний потенціал комунікативних стратегій учасників англомовного мікроблогінгу.

\section{ЛIТЕРАТУРА}

1. Бацевич Ф. Основи комунікативної лінгвістики: Київ: Вид центр Академія, 2004. 344c.

2. Бєссонова О. Оиінний тезаурус англійської мови: когнітивний $i$ тендерний аспекти. Дис. Київський нац. ун-т ім. Т.Шевченка, 2003.

3. Ерофеева Т. Языковая единица в гендерном рассмотрении// Вестник Челябинского государственного университета, 2008. С.35-39.

4. Земская Е., Китайгородская М., Розанова Н. Особенности мужской и женской речи. Москва: Наука, 1993.

5. Маслова Ю. Мовна репрезентація гендеру//Острозька академія. Вип.12. Острог, 2009.С. 224-233.

6. Прокопенко А. Інтерв'ю в передвиборчому американському дискурсі: структурно-семантичний та комунікативно-прагматичний аспекти. Дис. Сумський державний університет, 2013.

7. Пушкарева Н. Гендерная лингвистика и исторические науки// Этнографическое обозрение, N2, 2001.C.31-40.

8. Bonnie A. Nardi, Diane J. Schiano, Michelle Gumbrecht. Blogging as Social Activity, or would you let 900 Million People Read your Diary? Chicago, Illinois, USA, 2004.

9. Jespersen, Otto. Language: Its Nature, Development and Origin. London, 1922.

10.Caspar. "My Business Outside Of YouTube". 28 січень 2019.

11.Dr. Brené Brown. "Dr. Brené Brown on Joy: It's Terrifying | SuperSoul Sunday | Oprah Winfrey Network". 13 березня 2013.

12.Evan Carmichael. "The 5 LESSONS In Life People Learn TOO LATE". 9 вересня 2017.

13.Evan Carmichael. "The 40\% RULE That Can CHANGE Your Entire LIFE! | David Goggins". 22 березня 2019.

14. GabrielleBernstein. "How to Receive Signs from the Universe". 1 лютого 2015.

15.Jim Chapman. "PALM OIL \& ELEPHANT TREKKING | BORNEO PART ONE". 10 квітня 2019.

16.Joel from 'GALLUKS'. "SHOPPING IN SEOUL SOUTH KOREA!". 19 грудня 2018.

17.LDShadow Lady, "Channel Trailer". 12 червня 2015.

18.Megan Ellaby. "WHAT I BOUGHT IN NEW YORK". 19 серпень2018.

19.Mel Robbins. "STOP searching for your passion and do this instead | Mel Robbins". 3 жовтня 2018.

20.Miniminter. "She did this blindfolded *painful*". 12 січень 2019.

21.PewDiePie, "Ты Индия Ты проиграл". 11 травня 2018.

22.PewDiePie, "Что происходит?!". 29 січня 2019. 